\title{
A Study on Pigeon farming system in Hakimpur Upazila of Dinajpur District in Bangladesh
}

\author{
*Ashraful Hoque ${ }^{1}$, Hamida Khanom², Md Nahid Imtiaz Chowdhury ${ }^{3}$
}

123 Faculty of Veterinary Medicine, Chattogram Veterinary \& Animal Sciences University (CVASU), Khulshi, Chattogram-4225, Bangladesh,

E-mail: ashraful.cvasu@gmail.com, hamidakhanom21@gmail.com, nahidcvasu20@gmail.com

*Corresponding author
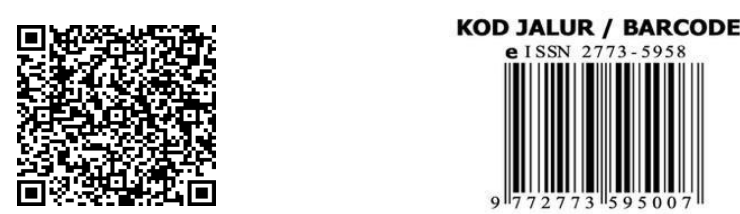

Date Received: April 25, 2021

Date Accepted: May 12, 2021

Date Published: May 23, 2021

Volume -2, Issue-2, May 2021

() ICRRD HIGH INDEX RESEARCH JOURNAL.

\begin{abstract}
A survey was carried out to investigate the pigeon farming system in Hakimpur Upazila at Dinajpur District (Bangladesh). The study was conducted during the period of October 2019 to December 2019. Data were collected from 10 farmers randomly. A questionnaire was developed to collect data from the selected farms located in Hakimpur Upazila. Collected data were different breeds, housing, feeding, management, marketing of pigeon, diseases and problems of farming. There were 8 different breeds in the ten farms. Average cost of housing per bird was 46 Taka and average height of house was $3.6 \mathrm{~m}$. The average feed intake was $37 \mathrm{gm}$ per bird per day. Per year production from a pair of pigeon were 9-10 pairs. The average body weight of per squab was found about $350 \mathrm{gm}$ to $400 \mathrm{gm}$ at 30 days of marketing age. Selling price varies from 150 Taka to 200 Taka per squab. Common diseases were Pox, ND, Salmonellosis and mineral deficiency affected the birds. The average mortality rate was $6 \%$. Around $25 \%$ farms were vaccinated by BCRDV and Pox vaccines. Most of the pigeon farmers rear pigeon in small scale scavenging system with supplementary feeding. The pigeon farming may be increased with government initiative providing training to farmers and extending loans. Further study is needed among different breeds and varieties of pigeon available in Bangladesh for better performance.
\end{abstract}

Keywords: Pigeon Farming System, Housing and Feeding, Pigeon Marketing, Hakimpur Upazila. 


\section{Introduction}

Pigeon, common name for members of the large family Columbidae, land birds, cosmopolitan in temperate and tropical regions, characterized by stout bodies, short necks, small heads and thick, heavy plumage (Gifford, 1941). Pigeons are related to human since ancient time. They live side by side with human as a source of food, hobby and experimental purposes (Sari et al., 2008). Pigeons are incredibly complex and intelligent animals. Pigeons (Order Columbiformes) are ubiquitous birds and can be found in virtually every town and city around the globe (Marques et al., 2007). They are highly dependent on humans to provide them with food and sites for roosting, loafing and nesting. Although pigeons are one of the most intelligent of all the bird species man has found limited uses for the birds other than for the purposes of sport, food and as a message carrier.

Bangladesh has a long historical record of raising poultry under backyard system (Bhowmik et al., 2014). The weather and vast areas of crop field along with housing premises of Bangladesh are suitable for pigeon farming (Asaduzzaman et al., 2009). More than $80 \%$ of the rural households' rear poultry (Haque, 1987). (Mbap, 1985) suggested that before attempting any genetic improvement, animals must first be characterized (FAO, 2010). The future utilization of genetic resource depends on breed characterization. Pigeons are mainly monogamous birds (Essam, 1997). The contribution of pigeon has not yet been considered in relation to the contribution of Livestock sub-sector and whole poultry production though the pigeons provide alternative source of animal protein. Comparatively low investment, less feed and housing cost involved, easy and economic husbandry practices, short reproduction cycle and less disease occurrence are observed for pigeon farming. Pigeons are used in natural beautification and ornamental birds as source of recreation, source of palatable, delicious and easily digestible animal protein.

Different sources of bio-fertilizer especially for family gardening and used as the laboratory animal in case of genetic and hormonal studies (Asaduzzaman et al., 2009). Hence profitable pigeon farming may be an easy and reliable source of employment opportunity, way of family labor utilization and cash income.

Sustainable and increasing rate of pigeon farming may enhance the rate of reducing the gap of animal protein deficiency; increase the rate of poverty reduction and it may improve the socio-economic status of the rural poor community (Asaduzzaman et al., 2009). In Bangladesh perspective some fancy pigeons especially Crowned pigeon, Jacobin, Fantail, Pouter, Swallow, Bokhara trumpeter and Frill back are reared as expensive items and it have aristocratic lifestyles (Kabir MA, 2015). In these pigeons for ornamental feathers which are the barriers for its normal breeding. So, trimming of the head-feather, leg and tail region is must in some cases. For the huge ornamentation of feathers those pigeons can't fly properly. So, it is easily maintained in a balcony or narrow space of the residence (Kabir MA, 2015). Giribaz is one of the oldest pigeons in Indo-Bangladesh subcontinent. Tumbler pigeons are come by lots of artificial selection. In Bangladesh perspectives the tumblers are very ancient (Kabir MA, 2015).

Among the farmers 50\% liked Gola, 37.5\% Giribaz, 5\% Siraji, 5\% Serting and 5\% Mayouri / Local breed of pigeon (Islam, 2010). The pigeon is able to consume simple feeds consisting of grains and a little good grit; the pigeon also needed clear water (Anggorodi, 1995). (Drevjany, 2001) Also reports that pigeon could be fed with feed that was made up of crumble ration or mixed of grins, minerals, grits and water. Among the feeds, pigeon liked grains such as corn, soya bean, peanut and wheat grain (Alwazzan, 2000). The meat derived from the early age of pigeon is called squab meat. The term squab is probably of Scandinavian origin; the Swedish word 
'skvabb' means 'loose, fat flesh' (Merriam-Webster's Collegiate Dictionary, 2009). People of all religions like squab meat. Squab meat is very lean, easily digestible and rich in proteins, minerals and vitamins. It is also used as tasty, delicate and fancy meat (Aliza, 2005; Jane, 2005; Richard, 2006; Morgan, 2006). Chinese people consider the meat of pigeons as having medicinal value and squab is a part of celebratory banquets for holiday such as Chinese New Year (Hsiung et al., 2005). Egyptians raised pigeon for food (Levi, 1972). Pigeon were popular in Romans, France and England as a means of Livelihood to produce squab (Goodwin, 1967).

In developing countries like Bangladesh, Pigeons are reared under semi scavenging system mainly for squab production. The quantity of feed supplied to semi scavenging pigeon from 32.5-42.5 gm/day, with an average of $38.1 \mathrm{gm} /$ day (Islam, 2010). Balance ration is one of the fundamental requirements to successful pigeon farming.

Optimum nutrition promotes proper growth, production and disease resistance (Levi, 1977). Several health problems but parasite infections play a major role. They constitute a major source of infection and transmission of diseases (Marques et al., 2007). The effects of parasitism on birds are often severs, including retarded growth, low egg production and susceptibility to other infections (Dranzoa et al., 1999).Although pigeons are susceptible to Pigeon Pox and New Castle Diseases.

The current study was conducted to record present status, problems and prospects and to formulate some suggestions about pigeon farming in Hakimpur Upazila, Dinajpur, Bangladesh.

\section{Materials and Methods}

The study was conducted from October 2019 to December 2019. The selected area was Hakimpur Upazila of Dinajpur district. 10 selected pigeon farms have been visited randomly and the different breeds of pigeons were recorded. Keeping in view the objectives of the study, the upazila was also chosen on information that people of this upazila has been rearing pigeon since long time. The interview schedule was carefully designed keeping the objectives in view. The schedule contained both open and closed from questions. Most easy, simple and direct questions were asked to obtain information. The parameters recorded are farmer personal information (age and educational level), housing, feeding, management and marketing of pigeon and squab, problems and prospects in pigeon farming by the farmers.

The collected data were complied, tabulated and analyzed as per objectives of the study. Qualitative data were converted into Quantitative forms by means of suitable score whenever needed simple tabular techniques were used to explain the data. Percentages were used mainly to illustrate the results. It is however to be noted that for analytical purpose, the cost and returns per bird and per family were estimated.

Table 1: Name of the Farm owners, Times of rearing, Number of pigeons and Breed's name

\begin{tabular}{|c|c|c|c|c|}
\hline Farms No. & $\begin{array}{c}\text { Name of the farm } \\
\text { owner }\end{array}$ & $\begin{array}{c}\text { Times of rearing } \\
\text { year(s) }\end{array}$ & $\begin{array}{c}\text { No. of pigeon } \\
\text { reared (In pair) }\end{array}$ & $\begin{array}{c}\text { Name of the } \\
\text { pigeon breeds }\end{array}$ \\
\hline 1 & Masud & 5 & 28 & $\begin{array}{c}\text { Giribaz, King, } \\
\text { Homer, Loton, } \\
\text { Deshi }\end{array}$ \\
\hline
\end{tabular}




\begin{tabular}{|c|c|c|c|c|}
\hline 2 & Afela & 2 & 31 & $\begin{array}{c}\text { Fantail, Deshi, } \\
\text { Giribaz }\end{array}$ \\
\hline 3 & Tarek & 1 & 14 & Lakha, Loton \\
\hline 4 & Marfudul & 3 & 10 & $\begin{array}{l}\text { Homer, Giribaz, } \\
\text { Deshi, Lakha }\end{array}$ \\
\hline 5 & Labu & 2 & 10 & $\begin{array}{l}\text { Deshi, Siraji, } \\
\text { Loton, Giribaz }\end{array}$ \\
\hline 6 & Dalim & 1 & 13 & Giribaz, Loton \\
\hline 7 & Sirazul & 1 & 18 & $\begin{array}{l}\text { Siraji, King, } \\
\text { Fantail }\end{array}$ \\
\hline 8 & Ilias & 5 & 25 & $\begin{array}{l}\text { Lakha, Homer, } \\
\text { Giribaz, Deshi }\end{array}$ \\
\hline 9 & Ikbal & 4 & 53 & $\begin{array}{c}\text { Chila, King, } \\
\text { Jacobing, Deshi }\end{array}$ \\
\hline 10 & Mamun & 1 & 16 & $\begin{array}{l}\text { Giribaz, Cropper, } \\
\text { Loton }\end{array}$ \\
\hline
\end{tabular}

Different types of data such as: No. of pigeon reared, Feed supply, Feed cost, No. of squab production per year, Marketing age, Body weight of squab, Price of squab, Mortality were showed below the table:

Table 2: Collection of Data from 10 Pigeon farms

\begin{tabular}{|c|c|c|c|c|c|c|c|c|c|c|}
\hline \multirow{2}{*}{ Parameter } & \multicolumn{9}{|c|}{ Farm No. } \\
\cline { 2 - 9 } & 1 & 2 & 3 & 4 & 5 & 6 & 7 & 8 & 9 & 10 \\
\hline $\begin{array}{c}\text { No. of pigeon reared } \\
\text { (In pair) }\end{array}$ & 28 & 31 & 14 & 10 & 10 & 13 & 18 & 25 & 53 & 16 \\
\hline $\begin{array}{c}\text { Feed supply (gm/ } \\
\text { day/pigeon) }\end{array}$ & 35 & 38 & 43 & 37 & 31 & 38 & 32 & 46 & 36 & 40 \\
\hline $\begin{array}{c}\text { Feed cost } \\
\text { (TK/month/pigeon) }\end{array}$ & 42 & 44 & 45 & 42 & 35 & 40 & 38 & 49 & 40 & 45 \\
\hline $\begin{array}{c}\text { No. of squab/year } \\
\text { Marketing age (days) }\end{array}$ & 32 & 430 & 210 & 160 & 120 & 180 & 230 & 300 & 830 & 240 \\
\hline $\begin{array}{c}\text { Body wt. of squab } \\
\text { (gm) }\end{array}$ & 300 & 200 & 280 & 280 & 350 & 230 & 300 & 230 & 350 & 300 \\
\hline $\begin{array}{c}\text { Price of squab } \\
\text { (TK/pigeon) }\end{array}$ & 150 & 110 & 130 & 120 & 150 & 120 & 130 & 110 & 150 & 130 \\
\hline \begin{tabular}{c} 
Mortality (\%) \\
\hline
\end{tabular} & 2 & 4 & 2 & 12 & 10 & 6 & 4 & 18 & 10 & 8 \\
\hline
\end{tabular}




\section{Results}

\section{Educational level of pigeon owner:}

Educational level of pigeon owner is an important indicator for pigeon rearing. The farmers were classified into 3 categories on the basis of their educational level. Data presented that most of the farmers 30\% were SSC and above, $30 \%$ farmers were class (1-10), 40\% farmers were Illiterate. Results revealed that pigeon farmers had lower educational level.

\section{Different types of feed supplied to the pigeon:}

The feeds supplied to the pigeons were Wheat, Mustard, Rice grain, Maize, Pea, Millet etc. The owners supplied feed two to three times daily. Feed ingredients were differing from availability of feed ingredients, seasons and areas.

\section{Disease incidence and Vaccination status:}

Pigeons were affected different type of diseases. These diseases were occurred due to infection by different Bacteria, Virus, Parasite and Fungus. The pigeons were mostly affected by Newcastle disease, Pox, Salmonellosis, Staphylococcosis and mineral deficiency as per the sign and symptoms shown by the bird and explained by the farm owners. Treatments were given mainly on the basis of sign and symptoms by the owner himself or by registered Veterinarian. Only $30 \%$ of the pigeon farms were vaccinated by Newcastle disease vaccine and Pox vaccine.

\section{Cost Benefit analysis of the pigeon farms:}

The cost benefit analysis of the pigeon farms was shown in Table 3. The data showed that the total average monthly income varies from $4450 \mathrm{TK}$ to $18,770 \mathrm{TK}$ due to the differences in the number of reared pigeons, breeds of pigeon, feed intake, feed cost, mortality and selling price.

Table 3: Cost benefit analysis of the 10 Pigeon farms

\begin{tabular}{|c|c|c|c|c|c|c|c|c|c|c|}
\hline Parameter & \multicolumn{9}{|c|}{ Farm No. } \\
\cline { 2 - 10 } & 1 & 2 & 3 & 4 & 5 & 6 & 7 & 8 & 9 & 10 \\
\hline $\begin{array}{c}\text { No. of pigeon } \\
\text { reared (In pair) }\end{array}$ & 28 & 31 & 14 & 10 & 10 & 13 & 18 & 25 & 53 & 16 \\
\hline $\begin{array}{c}\text { No. of squab } \\
\text { production /year } \\
\text { (Average 2 squab } \\
\text { produce per } \\
\text { month/pair) }\end{array}$ & 450 & 430 & 210 & 160 & 120 & 180 & 230 & 300 & 830 & 240 \\
\hline $\begin{array}{c}\text { Feed intake } \\
\text { (gm/day/pigeon) }\end{array}$ & 35 & 38 & 43 & 37 & 31 & 38 & 32 & 46 & 36 & 40 \\
\hline
\end{tabular}




\begin{tabular}{|c|c|c|c|c|c|c|c|c|c|c|}
\hline $\begin{array}{c}\text { Feed cost } \\
(T K / m o n t h / p i g e o \\
\text { n) }\end{array}$ & 42 & 44 & 45 & 42 & 35 & 40 & 38 & 49 & 40 & 45 \\
\hline Mortality (\%) & 2 & 4 & 2 & 12 & 10 & 6 & 4 & 18 & 10 & 8 \\
\hline $\begin{array}{c}\text { Selling price of } \\
\text { squab } \\
\text { (TK/pigeon) }\end{array}$ & $\begin{array}{l}150- \\
800\end{array}$ & $\begin{array}{l}100- \\
750\end{array}$ & $\begin{array}{c}150- \\
500\end{array}$ & $\begin{array}{c}150- \\
650\end{array}$ & $\begin{array}{l}150- \\
750\end{array}$ & $\begin{array}{l}100- \\
800\end{array}$ & $\begin{array}{c}150- \\
500\end{array}$ & $\begin{array}{l}150- \\
600\end{array}$ & $\begin{array}{c}100- \\
550\end{array}$ & $\begin{array}{l}100- \\
800\end{array}$ \\
\hline $\begin{array}{l}\text { Average selling } \\
\text { price of squab } \\
\text { (TK/bird) }\end{array}$ & 475 & 425 & 325 & 400 & 450 & 450 & 325 & 375 & 325 & 450 \\
\hline $\begin{array}{l}\text { Average selling } \\
\text { price of adult } \\
\text { pigeon (TK/bird) }\end{array}$ & 900 & 850 & 700 & 550 & 600 & 750 & 950 & 650 & 750 & 600 \\
\hline $\begin{array}{c}\text { Total average } \\
\text { income } \\
\text { (TK/month) }\end{array}$ & 14731 & 11975 & 5250 & 4864 & 4450 & 6735 & 6989 & 5075 & 18770 & 8260 \\
\hline
\end{tabular}

Explanation of farm no: 01 (Cost benefit analysis)

$$
\begin{aligned}
\text { Feed Cost } & =(56+38) \times 42 \\
& =94 \times 42 \\
& =3948 \mathrm{tk} / \text { month } \times 12 \\
& =47376 \mathrm{tk} / \text { year }
\end{aligned}
$$

$$
\begin{aligned}
\text { Labor Cost } & =3000 \times 12+4000 \\
& =36000+4000 \\
& =40000 \text { tk /year }
\end{aligned}
$$

Total Cost $=$ Feed Cost + Labor Cost

$$
=(47376+40000) \mathrm{tk} / \text { year }
$$$$
=87376 \mathrm{tk} / \text { year }
$$

$$
\begin{aligned}
\text { Total Income } & =(56 \times 900)+(450 \times 475) \\
& =50400+213750 \\
& =264150 \mathrm{tk} / \text { year }
\end{aligned}
$$

Here, Adult pigeon price $=900 \mathrm{tk}$

Squab price $=475 \mathrm{tk}$
Here, Adult Pigeon number $=56$

Squab number $=450 \div 12=38 /$

Feed Cost $=42 \mathrm{tk}$

Here, Labor Cost $=3000$ tk $/ \mathrm{M}$

Bonus $=4000$ tk $/ \mathrm{Y}$

Profit $=$ Total Income - Total Cost

$$
\begin{aligned}
& =264150-87376 \\
& =176774 \mathrm{tk} / \text { year } \div 12 \\
& =14731 \mathrm{tk} / \text { month }
\end{aligned}
$$

\section{Discussion}

In Bangladesh, Under the Dinajpur district Hakimpur Upazila is a potential place for pigeon farming. Many types of pigeon are reared in this area, such as: Giribaz, Deshi, Siraji, Loton, Homer, King, Fantail, Lakha, Chila etc. A study was done on pigeon farming where 10 pigeon farms were selected randomly. Among all of the breeds, Giribaz was the largest proportion as reared of the pigeon farmer. (Asaduzzaman et al., 2007) 
reported that most of the pigeon farmers of Bangladesh had no idea about the breeds or varieties of pigeon. A picture was focused that most of the pigeon farmers are Illiterate. According to (Asaduzzaman et al., 2009), result revealed that pigeon farmers had lower educational level (53.3\% Illiterate and $46.7 \%$ Literate) in the context of Bangladesh.

Pigeons are quite territorial about their housing or nesting area (Castoro et al., 2008). In the current study, Pigeons were reared in semi-intensive system. Construction materials used for pigeon house were wood and bamboo. The house was placed at a reasonable height for the protection of pigeons against predator. The housing cost of pigeon was about TK 2.00/month/pair, appears to be very cheap and reasonable. Pigeon feed cost was TK 28 per $\mathrm{kg}$. Therefore, spending on feed $37 \mathrm{gm} /$ day for each pigeon was TK 1.00 per day. Feeding one pair of pigeon requires about 74gm of feed which costs about TK 2.00 per day. Monthly cost of feeding for a pair of pigeon was TK 60.00 .

Usually, Pigeons are reared as pairs. Therefore, male female ratio should be 1.00. (Levi, 1957) Indicated that male female ratio varied in different breeds and varieties. (Levi, 1957) reported marketing age varying from 25 to 35 days with an average of 30 days. During marketing, farmers carry their pigeon and squab in a special type of bamboo made cage called "Pingira". Some others carry them in a banana tree made "Khol". It is evident that the squab weight ranged from 200 to $300 \mathrm{gm}$ with an average of 258gm (Asaduzzaman et al., 2009).

Maximum production of squab was 18 numbers/year/pair and minimum production was 12 numbers/year/pair. There is a belief that a good commercial pair of pigeon should produce 18 to 20 squabs/year (Levi, 1957), whereas (Platt et al., 1937) recorded 11.4 squabs/pair/bird. The variation in squab's production may be due to differences in breed and area. The price of squab is high in comparison with that of other poultry meat because it is sold as fancy meat bird considering their palatability, delicacy and taste.

Domestic pigeons are affected with infectious diseases such as Salmonellosis, Colibacillosis, Staphylococcosis, Newcastle disease, Pigeon pox. Newcastle disease is a globally distributed avian disease that can cause severe economic losses in commercial poultry (Herdt et al., 2000). Pigeon pox is a slow spreading disease which is responsible for morbidity and mortality in all ages of pigeons. Mortality and morbidity related to pigeon pox virus infection may be very high in pigeons (Tripathy, 1991). During clinical manifestations of those diseases if proper treatment is applied the survivability of these birds can be increased, bringing more economic benefits to the owners and that's why by introduction of vaccines the important viral diseases can be controlled.

\section{Conclusion}

Pigeon farming in Bangladesh is a profitable business. But most of the owners of the pigeon farms were Illiterate that was recorded in this study. Feed was a major task here. Farmers didn't know the feed value and actual ration of pigeons. Farmer were not well conscious to clean pigeon lofts. So, they often faced a lot of problems especially Newcastle disease, Pox, Eye problems and Diarrhea. Most owners didn't know the actual characteristics of pigeons. So, when they bought it, some bad characteristics come and ultimately, they could not preserve the pure breed and not found real value. So, need to use very common disinfectants once a week. Feed ingredients, amount of feed, clean water all are very important to manage a commercial and well profit farm. Future study is needed for meat yield investigation of squab among different breeds and varieties of pigeon available in Bangladesh for better performance. A survey on pigeon population and their economic feasibility in Bangladesh should be done. 


\section{Reference}

Aliza G. (2005): Field guide to meat: How to identify, select and prepare virtually every meat, poultry and game cut, Quirk books, pp. 221-223.

Alwazzan (2000): Pigeon Meat Farm. Victoria. http://www.Alwazzan.com/

Anggorodi R (1995). Nutrisi Aneka TernaUnggas. PT. Gramedia Pustaka Utama. Jakarta.

Asaduzzaman M, Mahiuddin M, Howlider MAR, Hossain M and Yeasmin T (2009). Pigeon farming in Gouripur upazilla of Mymensingh district. Bangladesh Journal of Animal Science 38: 142-150.

Bhowmik N, Mia MM and Rahman MA (2014). Morphometric measurements, productive and reproductive performance of jalali pigeon. International Journal of Development Research 4: 908-911.

Castoro and Guhl.(2008).“Pairing Behavior of Pigeons Related to Aggressiveness and Territory” (Web article).The Wlson Bulletin. http:// elibrary. unm. edu/ sora/ Wilson/ v070n01 /p0057-p0069.pdf. Retrived 2008-04-07.

Dranzoa, C., Ocaido, M \& Katete, P. 1999. The ecto- gastro-intestinal and haemo parasites of live pigeons (Columba livia) in Kampala, Uganda. Avian Pathology. 28: 119-124.

Drevjany L (2001). Nutritional properties of squab meat. Research paper Hubbel Farm Canada http://www.Magma.ca/ laded/nutrition.html.

Essam AM (1997). Behaviour and management of pigeons. PhD, Faculty of Veterinary Medicine, Moshtohr, Zagazig University.

FAO (Food and Agricultural Organization). (2010). Draft guidelines for molecular characterization of animal genetic resources for food and agriculture. Rome: FAO.

Gifford, E. W. 1941. Taxonomy and habits of pigeons. Auk, 58: 239-245.

Goodwin D (1967): Pigeons and Doves of the World, Britain Museum National History, London, United Kingdom. pp. 446.

Haque, Q.M.E. (1987) Characteristics of two villages for farming system research. Farming System Research Programs, Bangladesh Livestock Research Institute, Savar, Dhaka, Bangladesh.

Herdt, P. D. and Devriese, L. (2000). Pigeons. In: Avian Medicine, by Tully, T. N., M. P.C. Lawton, G. M. Dorrstein (Eds.) Reed Educational and Professional Publishing Ltd. Oxford, UK., pp: 330

Hsiung DT, N Simonds and J Lowe (2005): The food of China: A Journey for food lovers, Murdoch books. pp. 125.

Islam MR (2010): Pigeon farming and meat yield of some genetic groups in Mymensingh district, MS Thesis, Department of Poultry Science, Bangladesh Agricultural University, Mymensingh, Bangladesh.

Kabir MA. 2015. Grading system of ten common fancy pigeons of Bangladesh. Integrated J of British 1(1): 19-26.

Levi W (1957). The Pigeon Sumter, S. C. Levi Publishing Company, Inc. p. 537. ISBN 0853900132. 
Levi W (1972): Making pigeons pay, Levi Publishing Company, Inc. Sumter, SC.

Levi W (1977): The Pigeon Sumter, S.C. Levi Publishing Company, Inc. pp. 507.

Marques, S.M., Quadros, R.M, Da-Silva, C.J. \& Baldo, M. 2007. Parasites of pigeons (Columba livia) in urban areas oflanges, Southern Brazil. Parasitol Latinoam. 62: 183-187.

Mbap ST and Zakar H (2000). Characterization of local chickens in Yobe state, Nigeria. In: The Role of Agriculture in poultry in poverty Alleviation.

Merriam-Webster's Collegiate Dictionary (2009): Squab.

Platt, C. S. and Dare, R. S. 1937. Squab production. New Jersey Agric. Exper. Station Bull. 634.

Sari, B., Karatepe, B., Karatepe, M. \& Kara, M. 2008. Parasites of domestic pigeon (Columba livia domestica) and wild (Columba livia livia) pigeons in Niğde, Turkey. Bull Vet Inst Pulawy. 52: 551-554.

Tripathy, D. N. (1991): Pox. In Textbook of Diseases of poultry, Calnek, B.W. Iowa State University Press, Ames, Iowa, 583. 